\begin{tabular}{|l|}
\hline 論 文 \\
\hline $51-\mathrm{B} 37$ \\
\hline
\end{tabular}

\title{
単相多分割形サイリス夕制御整流装置の多 重制御による交流側高調波電流の軽減
}

鉄道技術研究所

松橋登喜雄

\section{1. まえがき}

サイリスタ制御方式を採用した整流装置ては、電圧・ 電流の制御に伴って交流電流が著しくひずみ高調波が 発生する。乙の高調波電流の含有率は，サイリスタの 位相制御とともに大幅に変動し，軽減の対象となる高 調波の次数もふえてくる。

交流式電気鉄道の上うに，電源が単相て大地帰路回 路老含むき電系統老構成する場合では，交流側高調波 電流による影響も広籍囲となり，その軽隇に関しても 種々考慮がはらわ机ている。

サイリスタ制期伴って発生する高調波電流のうち 低次調波は, 主として, 咅電采統機器の温度上昇・機 器容量の低下・系統保護継電器類の詥動作等化影響を 与元，高次調波怔，言電系統化近接する弱電流線施設 に対する誘導障害・列車速度制御信号系への妨害等上 なる。このため交流式電鉄回路では，地上側の高調波 対策しして，变電所代設计られる力率改善用コンデン サを利用した第 3 調波フイル夕により，采統保護・軌 莺回路等使用される継電器類ては，低域フイルタな どにより，柇高調波特性をもたせ，また，通信回楾采 に対しては，高しゃへいを施したアルミ被ケーブルを 用いるなどが行なすれている。車両側での高調波軽隇 対策としては, 整流器用主变圧器の 2 次側巻線の分割 数增加, 漏㧈リアクタンスの增大, 共振形フイルタの 設置, 制御方法の改善等が行なわ机, 高調波電流の発 生上軗減汇関して多大の考慮がはらわれ，また多くの 提案がなされている(1)(2)。

Reduction of AC Side High Harmonics Current by Multiplex Control for Single Phase Multi-split Type Thyristor Control Rectifying Device. By Tokio Matsuhashi, Member (Railway Technical Research Institute, Japanese National Rail ways)

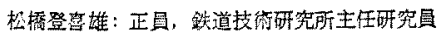

昭 $51-6$

最近石油ショックに伴いエネルギー問題が大きくと りあげられるようになり，国鉄において屯電鉄回路に おりる省エネルギー対策が検討され，サイリス多位相 制御に伴う高調波笔流の柽減に関する必要性が扎加ま ってきた。

単相で比較的大電力を扱う交流式電鉄回路の電気車 で法，サイリス夕制御整流装置として，高調波軽減の 目的で, 整流器用主変圧器の 2 次側巻線を 2 6 程度 に分割し，そのおのおのにサイリスタブリッジを設け る位相制御方式が用いられている。この場合，直流出 力柱，各サイリスタブリッジの直流倒を直列化接続し て負荷化供給される。乙の場合制御の具体的方法估， まず，第 1 分割のサイリスタブリッジ（2次側巻線か 含めて以下ニニットという）を制御し，他の各ユニッ トはすべて直流のみ導通する。次いで，第 1 ユニット の制御終了徯，第 2 二ニットの制御に入る。このとき 第 1 ユニットの動作はダイオードブリッジと同一の動 作となり直流出力心，第 1 ユニット(非制御動作) と 第2 ユニット(制御稕作) との和となる。このように, 多分割サイリス夕位相制御整流装置では，通常第 1 工 ニットから順番に制御するいわ吸る㮌序制很または皘 る重衩制御方式がとられる。

本諭文で新たに提案するサイリス夕の多重制衙に上 る交流側高調波電流の軽減方法は，多分割サイリス夕 制御整流装犆に求いて，各ユニットの制御位相を一定 角度だけずらせて多重制御することにより，直流電生。 電流の制御に関係なく, 交流側電流を多相化一定波形 とする制御方法である。この方法によ机ば，負荷上し て一定加速在得るような電動機運転の場合のように， 直流電流を一定制御卞る場合ては高調波含有量屯法 一定となる。さらに，多重制御における各ユニットの 制御位相角を適当に選ふことにより，特定の高調波の 
発生をほぼ零とすることも可能で，高渭波柽堿の対策 上しては，有効な方式と考无られる。

\section{2. モデル波形と高調波含有量}

2.1) 回路構成之波形単相多分割形少イリス 夕制御整流回路の例として, 整流器用主変正器の 2 次 側巻線が 4 分割の場合在第 1 图化示す。

徒来，この整流回路态用いたサイリス夕制御では，

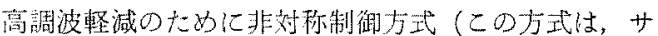
イリスタブリッジ仗妵いて，各アームのサイリス夕を 単独に制御し，直流出力電正に負の電王が出ない制御 方式で，のちに述べる対称制御は，向い合ったブリッ ジアームのサイリス夕在同時化点孤する方法で，ての 場合，出力電圧には目の部分が生じる)汃用いられる。 その動作は第 1 図化招いて最初，第 1 ユニットの制御 を行なう。そのとき第2 第 4 ユニットのサイリスタ は，直流 $I_{d}$ を通過させるため，サイリス夕 $22 ， 23$, 32，33，42，43 亿点弧信号办継続して送ら九る。ま ヨ゙，第 1 二ニットの電生位相 $\alpha$ でサイリスタ $11 ， 13$ 点弧し直流䉓流 $I_{d}$ が流机る。位相 $\pi$ でサイリスタ 12 にゲート信号が送られると, サイリスタ 12 は等通 し，サイリスタ 11 の时加電压が逆極性となるためサ イリス夕11加消弧する。

次で位椙 $\pi+\alpha$ でサイリスタ 14 に点弧信号が送ら 机るとサ1リスタ 13 は消弧して第 1 分割巻線加第 1 サイリスタブリッジ代電压が加えられる。なお，第

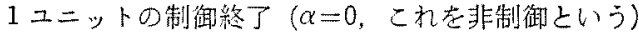
をむって，第 2 ユニットの制御へと進むとととなる。 以下同様汇制御老進的召。

直流側の平滑リアクトルを非常に大きいとし，加つ 交流側転流リアクタンスを無視して各部の電圧・電流 波形の概形をモデル的に示吉と第 2 図の上うになる。 なお，図は $(m-1)$ 個のユニットは非制で，第 $m$ ユニットが制御中の場合である。波形は位相制御の特 微として交流側ては，電流がひずみ，直流側では電圧

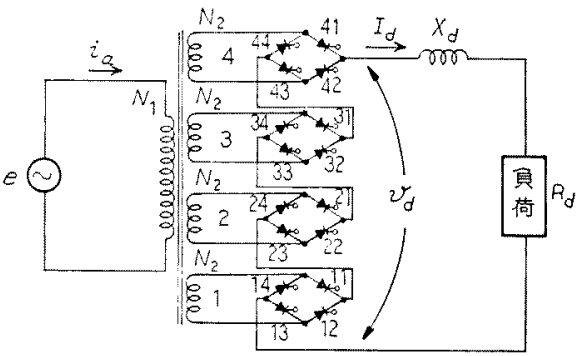

第 1 図 多分割サイリス夕制御整流回路

Fig. 1. Multi split thyristor control rectifying circuit.
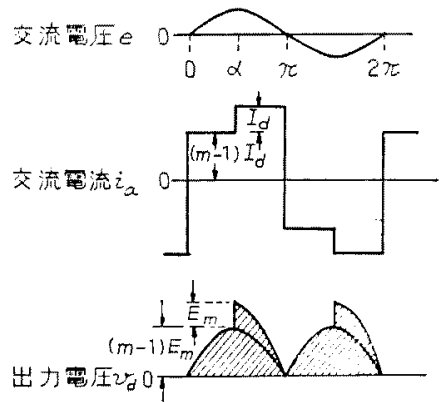

第 2 図 非対称制御の電任電流波形

Fig. 2. Voltage-current waveform for asymmetrical control.

がひずんでいる。次化対称制御を使用した從来の制御 方法法，非対称制御の場合之同㥞，第 1 ユニットから 順次制御するか，乙こでは，最初第 1 ニニットの電生 位相 $\pi / 2$ で点弧制御し，通流角を $\pi$ に遙ふでのとき 直流電圧は，プラス側半波の $1 / 2$ とマイナス側半波の $1 / 2$ との平均電圧となりここでは零となる。次で，サ イリス夕の点弧制御角を $\pi / 2$ 加ら零の方向代移すと, 值流笔圧は平均電压としてプラス側に增加することと なる。点弧制御角が 0 になると第 1 ニニットの制御が 終了する。制御中に打ける交流電流は，通流角が一定 で位相のみ变化するので高調波はほぼ一定で力率が変 化する。

次いで第 2 ユニットの制御に入ると直流電圧，交流

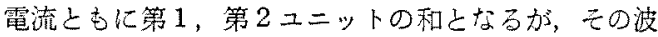
形は，非対称制御に招いて，第 1 ，第 2 ユニットを一 つのユニットとして制御した場合と同一となる。な

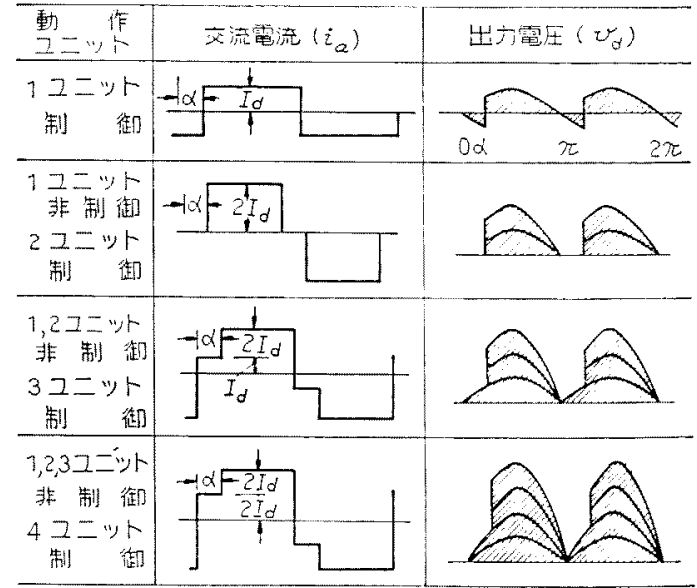

第 3 図 対称制御の電圧電流波北

Fig. 3. Voltage-current waveform for symmetrical control. 


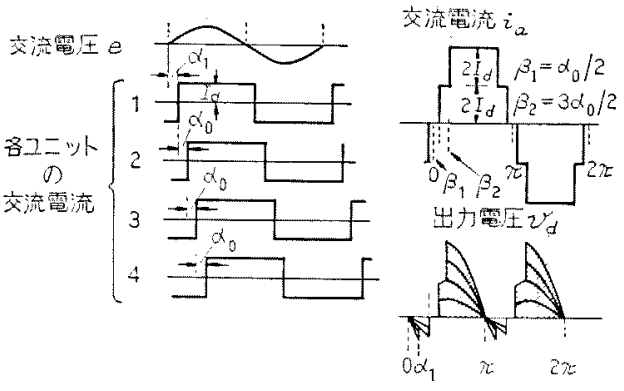

第 4 图多重制御の眥王電流波形 (4 分割)

Fig. 4. Voltage-current waveform for multiplex control.

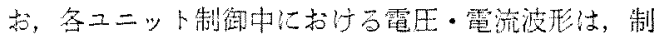
海ユニットに上って大幅に異なり，根形を画くと第 3 图のようになる。

本論文で提案するサイリス夕攺重制御比よる交流側 高調波電流の俥減方法は，基本的汇法対称制御方式を 用いるものて古る。第 1 图の整流器用主变殴器の 2 次

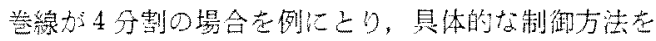
示すと次のと扔り上なる。い名，各ユニットの交流電 王同位相とし，位相 $\alpha_{1}$ で，符 1 二ニットのサイリ ス夕 11,13 在点弧し, 次いで $\alpha_{1}+\alpha_{0}$ の位相で第 2 ユニットのサイリスタ 21,23 を点弧する。さらに $\alpha_{1}$ $+2 \alpha_{0}$ の位相て第 3 ユニットのサイリス夕 31,33 を, $\alpha_{1}+3 \alpha_{0}$ て第 4 ユニットのサイリス夕 41,43 在順次 点㸸制得し，各ユニットの通流角点 $\pi$ に選んで詨称制 御老行なう屯のである。

各部の電王・電流波形の棿形老従来制御方式の場合 と同樣な条件で画く之第4図のようになる。波形は上 加ら整流器用主变圧器 2 次㑡巻線の交流電圧(位相结 各ユニットと无同一とする)，㨁流電流，第 1 ，第 2 , 第 3 , 第 4 ユニットの交流很電流, 1 次㑡交流電流, 出力電圧の順である。なお，出力電压 $v_{d}$ の平均値が 直流電圧 $E_{a}$ で，この電压の制御は $\alpha_{0}$ の值を变えず 亿 $\alpha_{1}$ の值を変えることにより行なわ斿る。すなわ

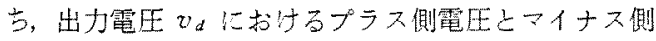

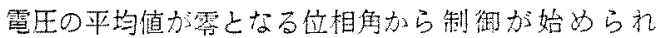

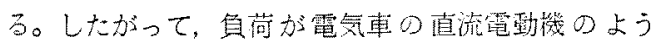
に，直流電流を定電流制御する摆合では，1 次側交流 電流の波形は，制御量に関係なくはほ定波形亡な る。な拉，本多重制御の場合，主㛄任器 2 次側分割数 $m$ の腢数・奇数によって出力電压 $v_{d}$ 及び 1 次側交流

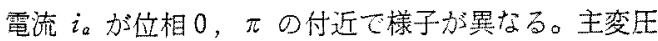
器 2 次㑡分割数が奇数の場合の例として,$m=5$ の場 合を第 5 图として示す。

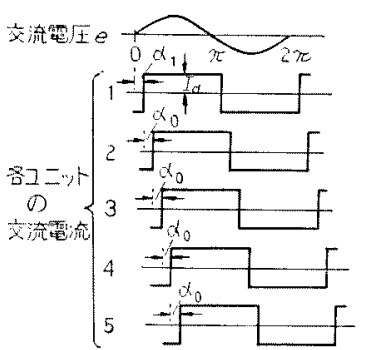

$$
\text { 资流靄流 } i_{a}
$$

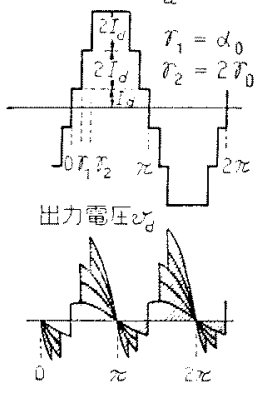

第 5 図多重制期の電王電流波形

Fig. 5. Voltage-current waveform for multiplex control.

〈2.2〉高調波合有量交流電流中に含まれる高 調波は，得られた波形についてフーリ工采数を求める ことにより計算することができる。いま，直流電圧志 $E_{d}$ ，交流倒の $n$ 次調波電流の振幅在 $A_{n}$ 亡方召。 籍2四の非效称方式ては，

$$
E_{i d}=\frac{E_{m}}{\pi}(2 m-1+\cos \alpha)
$$

ただし $E_{m}=2$ 次巻線の交流電压振的, $m=2$ 次卷線中の動作分割数， $\alpha=$ 制御ユニットの 制御位相角

$$
\begin{aligned}
& A_{n}= \frac{1}{N} \cdot \frac{2 \sqrt{2} I_{d}}{n \cdot \pi} \\
& \cdot \sqrt{2 m i^{2}-(2 m-1) \cdot(1-\cos n \alpha)}(2) \\
& \text { ただし } N=N_{1} / N_{2} \text { (巻数比), } I_{d}=\text { 直流電流 }
\end{aligned}
$$

として求的ら㣗る。

第3図の対称制御方式では,

$$
E_{a}=\frac{2 E_{m}}{\pi}(m-1+\cos \alpha)
$$

$$
\left.\begin{array}{rl}
A_{n} & =\frac{1}{N} \cdot \frac{4 I_{d}}{n \pi} \text { (第 } 1 \text { ユニット動作中) } \\
& =\frac{1}{N} \cdot \frac{4 I_{d}}{n \pi} \sqrt{2+2 \cos n \alpha} \text { (第2 ユニット制御中) } \\
& =\frac{1}{N} \cdot \frac{4 I_{d}}{n \pi} \sqrt{5+4 \cos n d} \text { (第3 ニニット制御中) } \\
& =\frac{1}{N} \cdot \frac{4 I_{d}}{n \pi} \sqrt{10+6 \cos n \alpha}
\end{array}\right\}
$$

(第 4 ユニット制御中)

として求的られる。

本諭文て提案する第 4 図，第 5 図の多重制御方式て は、

$$
E_{a}=\frac{2 E_{m}}{\pi}\left[\sum_{k=1}^{m} \cos \left\{\alpha_{1}+(k-1) \alpha_{0}\right\}\right]
$$




$$
\left.\begin{array}{rl}
A_{n} & =\frac{1}{N} \cdot \frac{8 I_{d}}{n \pi}\left\{\sum_{k=1}^{m / 2} \cos n\left(k-\frac{1}{2}\right) \alpha_{0}\right\}(m: \text { 偶数 }) \\
& =\frac{1}{N} \cdot \frac{4 I_{d}}{n \pi}\left\{1+2\left(\sum_{k=1}^{m-1 / 2} \cos n k \alpha_{0}\right)\right\}(m: \text { 奇数 })
\end{array}\right\}
$$

となる。

〈2.3〉他の諸量 サイリス夕制御整流装置の交 流側高調波電流による妨害の程度は，その対象とする 菜によって異なる。

交流式電気鉄道のき電采統では, 户電用变圧器, 周 波数変换機, 進相用コンデンサ等の温度上昇, 容量低 下，並びに采統保護のための継電器類の誤動作などの 原因として，第 3 調波並びに低次調波の存在が問題上 なる。いまひずみ率を $K_{1}$ とすれば

$$
K_{1}=\frac{\sqrt{\sum_{n=3.5}^{\infty} A_{n}{ }^{2}}}{A_{1}}
$$

で与るら斿。

弱電流楾施設采に対する妨害のうち，鉄道信号の采 綝対しては，主として列車位置強知，速度指合等に 用いられている周波数带として，商用周波の1/2また は 400〜1, $500 \mathrm{~Hz}$ が問題とされ，通信回線に及ぼす誘 漳障害に関するむのとしては，CCITT（国際電信電話 諮問委員会）の指示書に基づく $800 \mathrm{~Hz}$ を基隼しした 音声明りょう度の低下を加味して定めら机ている等価 妨害電流で評洒さ机る。これを $J_{p}$ とおけば

$$
J_{p}=\frac{1}{V^{2}} \cdot \sqrt{\sum_{n=1.3}^{\infty}\left(A_{n} \cdot S_{n}\right)^{2}}
$$

ただし， $A_{n}=n$ 次調波電流の振幅, $S_{n}=n$ 次調波に対吉る評価係数

でえられる。

力率 $\cos \varphi$ は, 実効電力すな和真荷電力を皮相 電力で除した值に定義される。

说来方式 (非対称制御) に怙ける直流電圧は，(1) 式で与えられているので負荷電力 $P_{0}$ は

$$
P_{0}=\frac{I_{d} E_{m}}{\pi}(2 m-1+\cos \alpha)
$$

七些艺られる。

一方， 1 次側交流電流 $i_{a}$ の実勃值 $I_{a}$ は

$$
I_{a}=\frac{1}{N} \sqrt{\sum_{n=1.3}^{\infty} A_{n}^{2} / 2}
$$

で表放される。

1 次側交流電王 $e$ の実効植 $E_{d}$ は $N \cdot E_{m} / l / \overline{2}$ C あるので, 力率 $\cos \varphi$ は

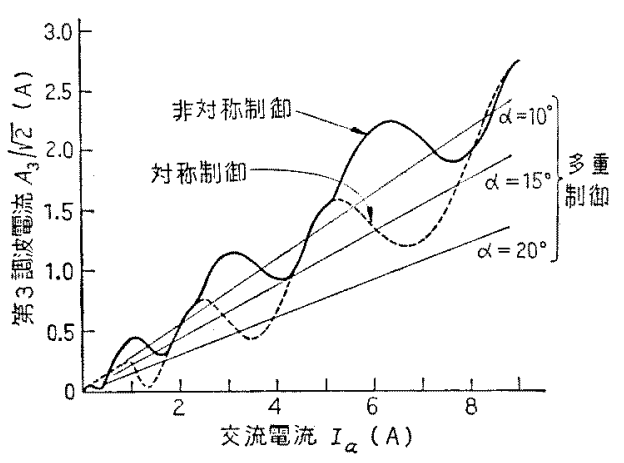

第 6 圆 第 3 調波電流の計算結果

Fig. 6. Calculation result of third harmonics current.

$$
\cos \varphi=2 P_{0} / E_{m} \cdot \sqrt{\sum_{n=1.3}^{\infty} A_{n}^{2}}
$$

で与えられる。

次に従来方式のうち対称制御の場合では，負荷電力 $P_{0}$ は,

$$
P_{0}=\frac{2 \cdot E_{m} I_{d}}{\pi}(m-1+\cos \alpha) .
$$

でえられ，力率 $\cos \varphi$ は (11) 式と同様となる。

本諭文で提案する等重制御の場合では，有効電力 $P_{0}$ 标

$$
P_{0}=\frac{2 E_{m} I_{d}}{\pi}\left[\sum_{k=1}^{m} \cos \left\{\alpha_{1}+(k-1) \alpha_{0}\right\}\right]
$$

となる。したがって，力率 $\cos \varphi$ は，

$$
\cos \varphi=\frac{4 \cdot I_{d}\left[\sum_{k=1}^{m} \cos \left\{\alpha_{1}+(k-1) \alpha_{0}\right\}\right]}{\sqrt{\sum_{n=1.3}^{\infty} A_{n}{ }^{2}}} \ldots
$$

で与えられる。

$\langle 2.4\rangle$ 数值計算例 整流器用主変圧器の 2 次例 が 4 分割の場合について数值計算を行ない，往来制御 と多重制期を比較すると第6图〜第 10 図のようにな bo

第 6 因估交流側電流 $I_{a}$ と第 3 調波 $A_{3} / V \overline{2}$ 関保 を示したものて，往来方式では，非对称制御，対称制 御ともに，位相制期に伴い第 3 調波の含有率が大幅に 变動し，各ユニット制御に㧍ける最大徝を連ら打た值 は非対称制御で約 39\%，対称制御で約 30\%となっ た。本多重制御の場合は, 各工二ットの点㧓位相差 $\alpha_{0}$ によって值は異なるが, 第 3 調波は交流電流の増加と ともに直線的に堌大し， $\alpha_{0}=10^{\circ}$ では，含有率しして 約 $27 \%, \alpha_{0}=20^{\circ}$ では約 $15 \%$ 程度となる。 


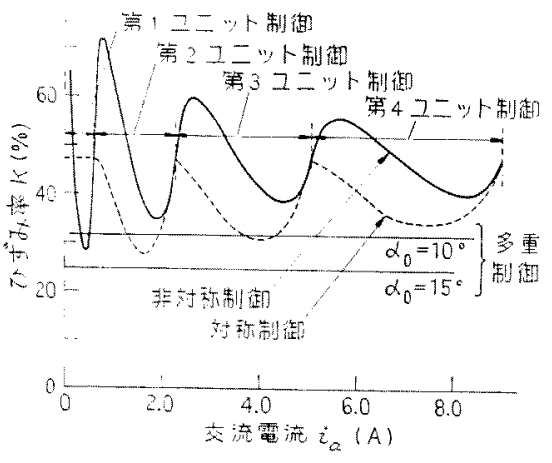

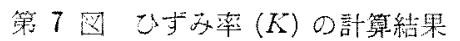

Fig. 7. Calculation result of distortion factor.

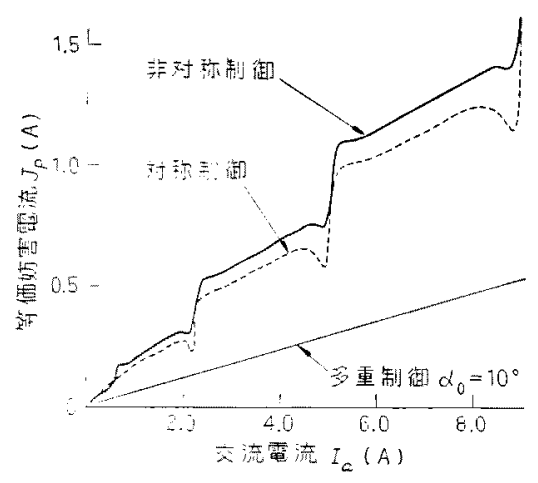

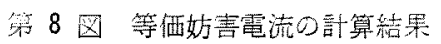

Fig. 8. Calculation result of equivalent interference current.

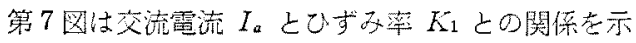
したものである。往来制御のうち非效制御では，第 1 ユニット制御中交流電流は， $\alpha \sim \pi$ 项: $\pi+\alpha \sim 2 \pi$ のパルス状波形七なるのて， $\alpha$ の变化隹徒って高調

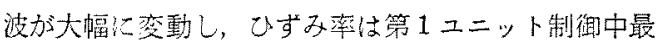
大となる。制御分割加第 2 , 第 3 , 第 4 ユニットへの と淮むに徒って電流波形は，非制御分割亡制御分割と

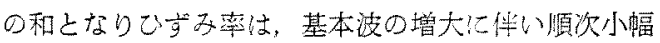
の落瞽となった。

往来制湖のうち对称制御では，筆1 ユニット制微中

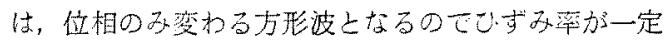
做を示し，第 2 二ニット制御中ては，第 1 ，第 2 分割 老1つのユニットとした位相制期しなるので高調波の 变動加大きくなり，ひずみ率も変動するしととなる。 な方，第 3 ，第 4 ユニット制御中も第 2 ユニット制御

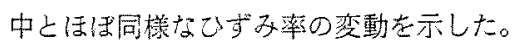

本多重制彻の場合では，交流電流の大きさに関係な く制御中て李ひずみ率加一定で各分割の制㑡位相差 $a_{0}$ によってしずる率の相違することが判る。

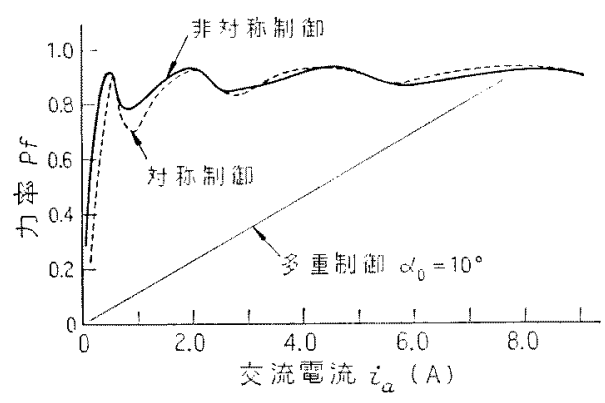

第 9 图力率の計算結果

Fig. 9. Calculation result of power factor.

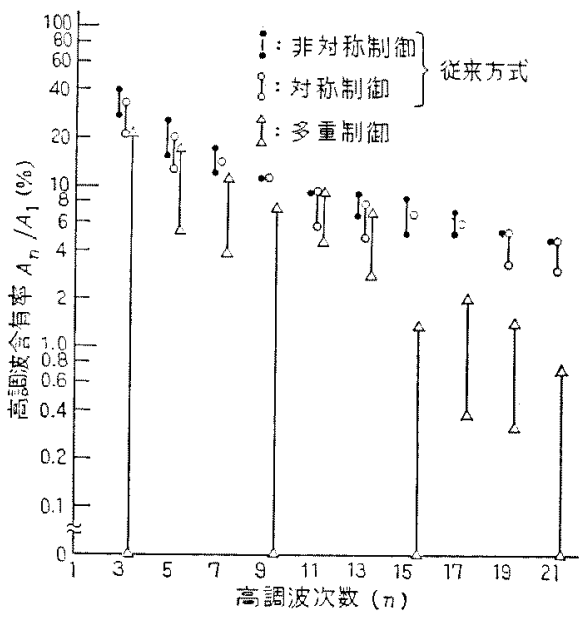

第 10 因高調波の部算結果

Fig. 10. Calculation result of high harmonics.

第8圂は等価妨害電流 $J_{p}$ の計算結果である。多重 制御は，证涞制御の各場合に比べて大幅に減少し，顕 荷電流の増加に比例して増大することが判る。

第 9 図は力率 $\cos \varphi$ の哔算結果を示したものである。 多重制御は往考制御に比べて交流電流の小さい簛囲て 力率が悪く、交流電流が大きくなるとほぼ同一となる。 なお，電䌝車に単相整流装䈯を使用する交流式電鉄回 路においては，電力回生制勧を行なうためにサイリス タブリッジ制御を使用することは不可尔のことで, 力 率の瑟化はサイリスタ位相制御方式老採用した堨合の

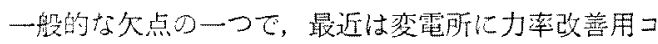
ンデンサが設備さ机るようになった。なお，本多重制

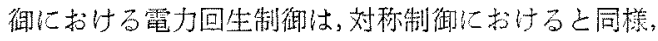
直流則負荷としての直流電動機について，乙の界磁差 線の接続范替え他励磁発電機とし，多重制御に志ける 主移相器を力行時上反対力向，才なわち $\pi / 2 \rightarrow \pi$ およ び $3 \pi / 2 \rightarrow 2 \pi$ の方向八制制芯進めることにより電力回 生制御が行长机る。 


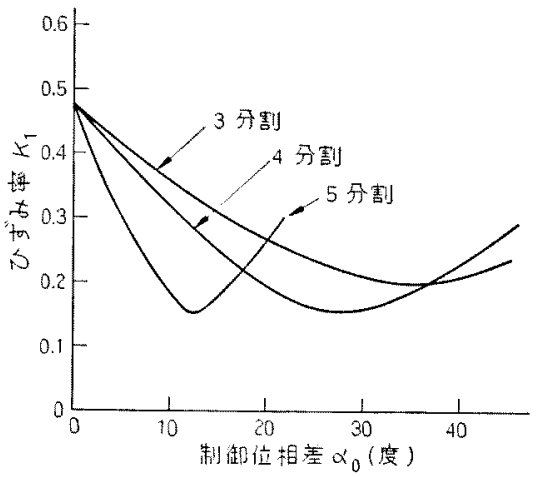

第 11 图制御仿相差 $\left(\alpha_{0}\right)$ とひずみ率 $\left(K_{1}\right)$ の関係

Fig. 11. Relation of controlphase difference $\left(\alpha_{0}\right)$ and distortion factor $\left(K_{1}\right)$.

第 10 図は各制御方式に如りる高調波含有率の計算 結果去したものである。

従来制御方式（非対称制御，対称制御）では，第 7 図加らも分る上うに，制御ユニット加進むに徒って， 基本波が大きくなり高調波含有率としては低下の傾向 を示すようになるか，ここでは第 4 ユニット制御中に 抬ける最大および最小のひず率となる場合の高調波 含有率を示した。本多重制御に求ける高調波含有率は, 制御位相差 $\alpha_{0}$ が 5 度扰よびひずる率が最小となる 30 度について示した。

従来制御では，非対称制御，対称制御いずれの場合 も多重制御の場合より高調波含有率の大きいととが判 る。なお，本多重制御で估， $\alpha_{0}$ がある值老とると高 調波含有率が特に小さくなる次数が発生し， $\alpha_{0}$ が大 きい場合概して高調波含有率の少くなる傾向が知られ た。なお，乙の $\alpha_{0}$ に成して特に高調波含有率の減少 する次数のあることは，本多重制御の特徴上考元 られる。すなっち, いま, 整流器用主变圧器の 2 次側 が 3 分割の場合を例にとると（6) 式に战いて，1+2 $\cos n \alpha_{0}$ の項肪零の場合を考えると $\cos n \alpha_{0}=-1 / 2$ と なる。したがって， $n \alpha_{0}=k \pi \pm \pi / 3$ (ただし $k=1,3 ，$ $5 \cdots)$ なる条件で高調波次数 $(n)$ の発生肪雾们抑えら れることとなる。

また， 2 次側か 4 分割の場合を例にとると，(6)式 より $\left\{\cos \left(n \alpha_{0} / 2+\cos \right) n 3 \alpha_{0} / 2\right\}$ の項が零亡なる条件, すなわち, $n \alpha_{0}=k \pi / 2$ 及び $n \alpha_{0}=k \pi(k=1,3,5 \cdots)$ のとき $n$ 次の高調波の発生が零に抑制さ机るととと なる。次に各分割における制御位相差 $\alpha_{0}$ とひずみ率 の関係を示すと第11図のようになる。結果では， $\alpha_{0}$ が 3 分割で 35 度, 4 分割で $25 \sim 30$ 度, 5 分割では 10〜15 度の各場合にひずみ率が最小となるととが判

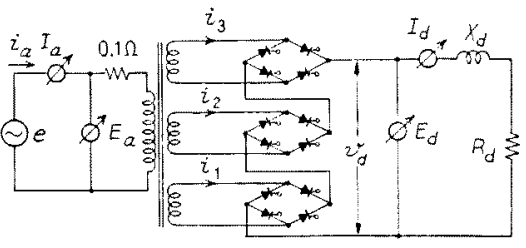

籍 12 因 奏験回路

Fig. 12. Experimental circuit.

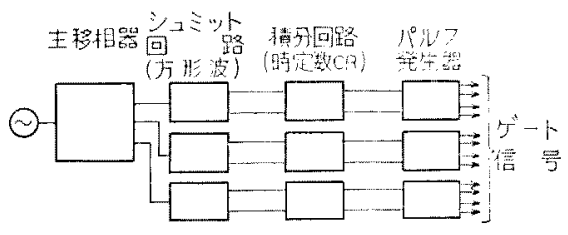

籍 13 区 制微信骂発生器口構成㘣

Fig. 13. Block diagram of gate turn-on signal generator.

る。

\section{3. 実験結果}

〈3・1〉実験回路並びに方法実騟回路は第 12 図に示したように, 整流器用主変圷器として, 容量 $200 \mathrm{VA}, 1$ 次電王 $100 \mathrm{~V}, 2$ 次電生 $15 \mathrm{~V} \times 3$ 在使用し た。ここに使用した変哭器の漏れリアクタンス法, 一 次短絡で 2 次側 - 巻線当り $0.1 \Omega$ (平均值)である。 直流側㲹そう入した平滑りアクトル及び負荷は，空心 コイルを使用し，亏の值は， $X_{d}=18.8 \Omega, R_{d}=6.0 \Omega$ であった。なお，てれらの定数は，実験室にありあわ せた素子を使用したものでる。

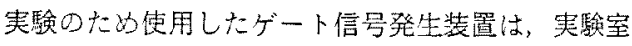
で製作したもので，そのブロックダイヤグラムを示す と第 13 図のようになる。すなわ方，実験回路之同一 の商用周波数電源主主移相器に入力として加元, 出力 を6 組のシユミット回路に導き，プラス側方形波およ びマイナス侧方形波を作り，皘分回路を経てユニジャ ンクショントランジスタ(UJT) に上り制御パルスを 発生し，パルストランスを経て制御サイリスタのゲー トに制傕信号電流を送る装置とした。各ユニットのサ イリス夕の点弧位相差 $\alpha_{0}$ の調整は, 皘分回路の時定 数により，また，全体の制御位相 $\alpha_{1}$ の調整は，主移 相器によることとした。

$\langle 3 \cdot 2\rangle$ 結 果 第 14 図虫実験回路各部の電代電 流波形をシンクロスコープで観測したものの一例でお る。（a）図は從来方式 (非対称制御)，（b）は多重制 御の場合である。住来制御の波形は， $0 ， \pi$ 江ける 


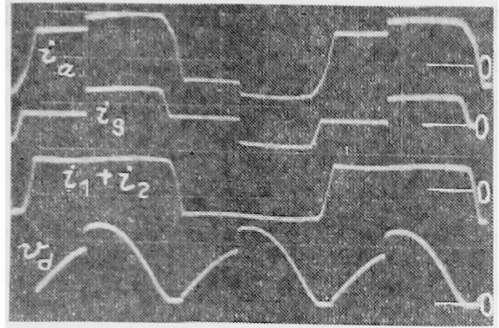

（a）従来方式 (非対称制御)

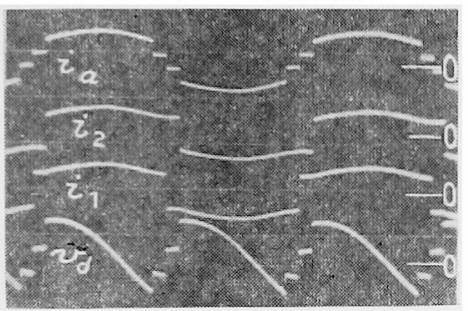

(b) 多重制御（3 分割）

第 14 図 実験中の各部の電圧電流波形

Hig. 14. Voltage-current waveform of each part undertest.

転流では若干時間を要し, 制御位相での転流は瞬時に 行なわれている。これは転流時の電圧位相に関係する ためと思われる。多重制御では一次側交流電流が多相 化波形を示し, 高調波の少ないことが判る。また, 各 制御位相にお污る転流は, 各ユニットの交流電流波形 で判るように，電流位相が嘈時に転換しモデル化波形 における仮定がほほ満足されていることが同かがわ机 る。

第 15 図は主変圧器 2 次側が 3 分割の場合における 多重制御の 1 次側交流電流の高調波分析結果を示した むので, 制御位相差 $\alpha_{0}$ は 18 度および 21.6 度の場 合である。なお，比較のため同図汇非対称制御（3工 ニット制御中 $\alpha=126$ 度）の実験結果並びに多重制御 $\alpha_{0}=20^{\circ}$ における計算結果を示した。結果によると, 多重制御は非対称制御に比べ第 11 次調波以下で含有 率の小さいことが判る。また, 多重制御では制御位相 差 $\alpha_{0}$ の相違に伴って特に軽減される高調波の移動す ることが知られる。

なお，計算結果との比較では，3，5，7，9，11 次 等低次調波でかなりの一致がみられたが, 第 15 調波 以上では，両者に若干の相違がみら礼る。この原因と しては，(1)制御位相差 $\alpha_{0}$ の調整不足, (2) サイリス 夕順方向電圧降下の省略, (3) 転流区間代おける仮定 と実験との相違等が考えら机る。な押, (3)の交流転流 リアクタンスの無視に伴う影響は, 高次高調波に最む 影響が大きいと考えられる。

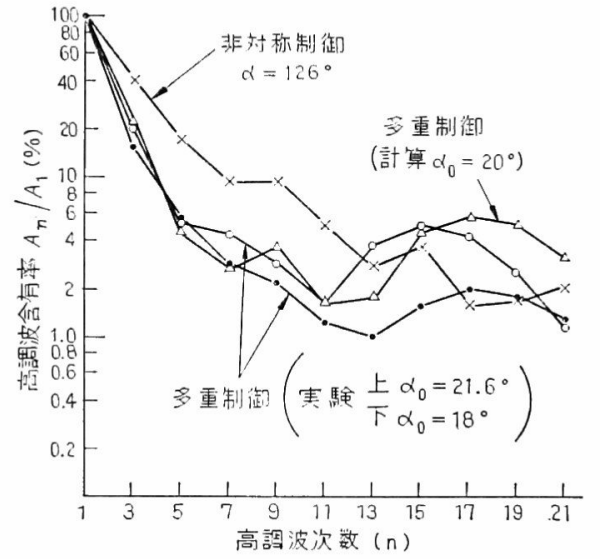

第 15 図実験例における対流電流の 高調波スペクトル

Fig. 15. High hamonics spectram of line current in a measured circuit.

\section{4. むすび}

本論文で提案する多重制御方式による交流側高調波 電流の軽減方法は, 多分割形サイリス夕制御整流装置 に打いて，位相制御の方式を若干変更するてとにより 得られる制御方式で，次の各特徵を持つことが容易に 知られる。

（1）サイリスタブリッジを採用した位相制御方式 の特性として, 高調波の增大および力率の悪化等が挙 げられるが, 本多重制御方式の採用により高調波の増 大をおさえることができる。

(2) 主変圧器 2 次側各分割の制御位相差を適当に 選ぶことにより, 特定の高調波次数の発生量を小さく おさえることができる。

（3）直流電動機負荷のように直流電流を一定制御 する場合では, 高調波電流の発生がほぼ一定となるの で高調波対策が容易となる。

（4）単相整流装置における交流側電流の高調波軽 減においては，主として交流側にフィルタが設けられ るが，交流式電鉄回路における電気車では，重量およ びスペースに極度の制限が加えられる。したがって， 本多重制御による高調波軽減では, 制御装置のみの変 更でよいので, 電気車等重量, スペースに制限のある 場合には有利な条件となる。

（5）本多重制御方式は，サイリスタブリッジ制御 方式の一つであるので電力回生制御えの応用として は, 従来方式の対称制御之同様負荷としての電動機の 界磁巻線の接続替え並びに制御位相を力行と反対方向 へ移相する等により比較的簡単に行なうことができ 
30

終和日に，サイリス名制御整流回路に打方交流側 高調波電流の軽減に関する一連の研究において，た无 ずご指嶈，で鞭挂を戴いている名古屋大学教授雨寰好 文博士に溧く感謝致します。

ミた，本多重制御方式に関して䅲々ご指導とじ助言 在戴いた，鉄道電化㙂会，パワーエレクトロニックス

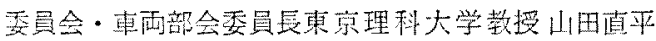

博士をはじめ副氶員長横浜国立大学教授池田吉爱博 土並び同委員会委員各位儿深く感謝致します。

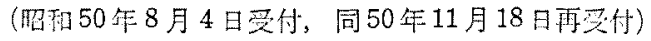

文献

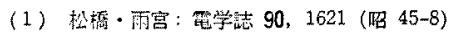

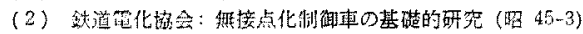

